\title{
Analysis of Factors Associated with Anemia in Pregnant Women at Prambanan Community Health Center, Sleman, Yogyakarta
}

\author{
Ratna Prahesti1), Dono Indarto²), Muhammad Akhyar3) \\ ${ }^{1)}$ Masters Program in Public Health, Universitas Sebelas Maret \\ 2)Faculty of Medicine, Universitas Sebelas Maret \\ 3)Faculty of Teaching and Educational Science, Universitas Sebelas Maret
}

\begin{abstract}
Background: Maternal anemia has serious impact on maternal and fetal health outcome. Pregnant women are at high risk of anemia. This study aimed to investigate the factors associated with the incidence of anemia among pregnant women.

Subjects and Method: This was an analytic and observational study with cross-sectional design. This study was conducted at Prambanan Community Health Center, Sleman, Yogyakarta. A total of 120 trimester II and III pregnant mothers, was selected for this study. The dependent variable was incidence of anemia. The independent variables were gestational age and maternal education. The data were collected by a questionnaire and analyzed by multiple logistic regression.

Results: Trimester II pregnant women had lower risk of anemia than trimester III $(\mathrm{OR}=0.35$; $95 \% \mathrm{CI}=0.15$ to $0.80 ; \mathrm{p}=0.013)$. Pregnant women completed high school had lower risk of anemia than lower education $(\mathrm{OR}=0.33 ; 95 \% \mathrm{CI}=1.29$ to $6.81 ; \mathrm{p}=0.010)$.

Conclusion: Gestational age and maternal education are associated with the risk of anemia in pregnant women.
\end{abstract}

Keywords: anemia, pregnant women, trimester II and III, maternal education

\section{Correspondence:}

Ratna Prahesti. Masters Program in Public Health, Universitas Sebelas Maret. Jl. Ir. Sutami 36A, Surakarta, 57126, Central Java.

\section{BACKGROUND}

Anemia is one of the most common and widespread global health problems and affects 56 million women worldwide, and two thirds of them are in Asia (Soh, 2015). In developing countries, anemia is a serious concern because its effects on the mother and fetus contribute to maternal death (Sharma, 2010).

According to Indonesia Basic Health study (2013), pregnant women are one group that is at high risk of anemia. Pregnant women can suffer from anemia due to iron requirements increase for the developing fetus during pregnancy. The results of pregnancy with anemia include intra uterine growth retardation (IUGR), premature birth, low birth weight (LBW), and an increased risk of neonatal death. The effects of anemia on maternal pregnancy include shortness of breath, fatigue, palpitations, sleep disturbances, increased risk of bleeding during labor, preeclampsia, and sepsis (Noran, 2015; Sharma, 2010).

Anemia is influenced by many factors, including gestational age, maternal education, family income, pregnancy interval, parity, consumption of blood-booster tablets, and history of illness. Anemia in trimester (TM) I and II are not associated with the incidence of LBW and preterm birth, while anemia in TM III has an influence on the incidence of LBW and preterm birth (Huang, 2015).

The contribution of anemia to death in Indonesia is estimated at $10 \%$ to $12 \%$. 
Based on statistical data from DIY Health Office (2012) regarding the number of pregnant women with anemia is $18.56 \%$ of 45,323 pregnant women and increased to $22.89 \%$ from 46,104 pregnant women in 2013 (DIY Health Office, 2013).

This study aimed to determine factors associated with the incidence of anemia in pregnant women in Prambanan Community Health Center, Sleman Yogyakarta to be important.

\section{SUBJECTS DAN METHOD}

This was a case control study. The purpose of multiple study methodology was to complement the description of the study results on the phenomenon under study and to strengthen the study analysis.

The method strategy used was a sequential explanatory strategy. In this study, qualitative data complements quantitative data. This strategy began with the collection and analysis of quantitative data which was then followed by the collection and analysis of qualitative data built on quantitative results. This strategy prioritized quantitative data. The study process in this strategy occurs when quantitative initial results inform the qualitative collection process, so that these two types of data are separated, but remain in touch (Creswell, 2012).

The instruments used in this study were questionnaires and interview guidelines. The type of questionnaire given was to provide closed questions. The interview guide contained a list of questions about the nine variables studied.

\footnotetext{
RESULTS

\section{Study Subject Characteristics}

Table 1 showed the mean of gestational age is TM III in the anemia group by $36.6 \%$. The mean of education on anemia and not anemia group was high school by $32.5 \%$. The mean of pregnancy interval was not at
}

risk in the anemia group by $48.3 \%$. The mean of parity was less than 2 children in the anemia group at $44.1 \%$. The mean of adherent to blood booster supplementation in the non-anemia group was $45 \%$. The average of blood booster consuming method using water in the non-anemia group was $40 \%$.

\section{Bivariate Analysis}

Based on the results of the analysis, Table 2 calculated the variable of gestational age by the correlation value between gestational age and anemia of $p=0.014$. The calculation of maternal education variables obtained the correlation value between education and anemia of $p=0.015$. Calculation of the pregnancy interval variable obtained the correlation value between the pregnancy interval and anemia at $\mathrm{p}=0.402$. The calculation of the parity variable obtained the correlation value between parity and anemia of $p=0.306$. The calculation of the blood booster tablets consumption compliance variable obtained the correlation value between compliance with blood booster tablets consumption and anemia of $\mathrm{p}=$ o.769. Calculation of the variable consumption method of blood booster tablets obtained the correlation value between how to consume blood booster tablets with anemia of $\mathrm{p}=0.810$.

\section{Multiple Logistic Regression Analysis}

Table 3 showed the $\mathrm{R}^{2}$ value of $21.4 \%$. This meant that $21.4 \%$ of the incidence of anemia could be influenced by gestational age and maternal education, while $78.6 \%$ was influenced by other variables such as area of residence, nutritional intake, antenatal care, nutritional knowledge, culture of abstinence, maternal nutritional status, pregnancy interval, blood booster supplementation, parity, maternal age, and how to consume blood booster tablets. 
Table 1. Frequency distribution of the study subject characteristics.

\begin{tabular}{|c|c|c|c|c|}
\hline \multirow[t]{2}{*}{ Variable } & \multicolumn{2}{|c|}{$\begin{array}{c}\text { Anemia } \\
(<11 \mathrm{~g} / \mathrm{dL})\end{array}$} & \multicolumn{2}{|c|}{$\begin{array}{c}\text { Not Anemia } \\
(\mathrm{TM} \text { II: }<10.5 \mathrm{~g} / \mathrm{dL} ; \text { TM III: }<11 \mathrm{~g} / \mathrm{dL})\end{array}$} \\
\hline & n & $\%$ & $\mathbf{n}$ & $\%$ \\
\hline \multicolumn{5}{|l|}{ Gestational age } \\
\hline - Trimester II & 16 & 13.3 & 29 & 24.1 \\
\hline - Trimester III & 44 & 36.6 & 31 & 25.8 \\
\hline \multicolumn{5}{|l|}{ Education } \\
\hline - Elementary & 2 & 1.6 & o & o \\
\hline - Junior High School & 10 & 8.3 & 17 & 14.1 \\
\hline - Senior High School & 39 & 32.5 & 39 & 32.5 \\
\hline - College & 9 & $7 \cdot 5$ & 4 & $3 \cdot 3$ \\
\hline \multicolumn{5}{|l|}{ Pregnancy interval } \\
\hline$-\quad<2$ years & 2 & 1.6 & 4 & $3 \cdot 3$ \\
\hline$-\quad>2$ years & 58 & 48.3 & 56 & 46.6 \\
\hline \multicolumn{5}{|l|}{ Parity } \\
\hline - $\leq 2$ children & 53 & 44.1 & 49 & 40.8 \\
\hline - $>2$ children & 7 & 5.8 & 11 & 9.1 \\
\hline \multirow{2}{*}{\multicolumn{5}{|c|}{$\begin{array}{l}\text { Blood booster } \\
\text { Suplementation }\end{array}$}} \\
\hline & & & & \\
\hline - Adherent & 53 & 44.1 & 54 & 45 \\
\hline - Non-adherent & 7 & 5.8 & 6 & 5 \\
\hline \multicolumn{5}{|l|}{$\begin{array}{l}\text { How to consume blood } \\
\text { booster tablets }\end{array}$} \\
\hline - Water & 47 & 39.1 & 48 & 40 \\
\hline - Tea & 10 & 10 & 11 & 9.2 \\
\hline - Orange juice & 3 & 2.5 & 1 & 0.8 \\
\hline
\end{tabular}

Table 2. Distribution of relationships between factors associated with anemia.

\begin{tabular}{|c|c|c|c|c|c|c|c|}
\hline \multirow[t]{2}{*}{ Variable } & \multicolumn{2}{|c|}{$\begin{array}{c}\text { Anemia } \\
(<11 g / \text { dL })\end{array}$} & \multicolumn{2}{|c|}{$\begin{array}{c}\text { Not Anemia } \\
\text { (TM II: }<10.5 \mathrm{~g} / \mathrm{dL} \text {; } \\
\text { TM III: }<11 \mathrm{~d} / \mathrm{dL})\end{array}$} & \multicolumn{2}{|c|}{$95 \% \mathrm{CI}$} & \multirow[b]{2}{*}{$\mathbf{p}$} \\
\hline & $\mathbf{n}$ & $\%$ & $\mathbf{n}$ & $\%$ & $\begin{array}{c}\text { Lower } \\
\text { limit }\end{array}$ & $\begin{array}{l}\text { Upper } \\
\text { limit }\end{array}$ & \\
\hline \multicolumn{8}{|l|}{ Gestational age } \\
\hline - $\quad$ Trimester II & 16 & $13 \cdot 3$ & 29 & 24.1 & 0.18 & 0.83 & 0.014 \\
\hline - Trimester III & 44 & 36.6 & 31 & 25.8 & & & \\
\hline \multicolumn{8}{|l|}{ Education } \\
\hline$\geq$ High school & 30 & 25 & 43 & 35.8 & 1.19 & $5 \cdot 39$ & 0.015 \\
\hline$<$ High school & 30 & 25 & 17 & 14.1 & & & \\
\hline \multicolumn{8}{|l|}{ Pregnancy interval } \\
\hline $\begin{array}{l}-\quad<2 \text { years } \\
-\quad \geq 2 \text { years }\end{array}$ & $\begin{array}{c}2 \\
58\end{array}$ & $\begin{array}{c}1.6 \\
48.3\end{array}$ & $\begin{array}{c}4 \\
56\end{array}$ & $\begin{array}{c}3.3 \\
46.6\end{array}$ & 0.08 & 2.74 & 0.402 \\
\hline \multicolumn{8}{|l|}{ Parity } \\
\hline $\begin{array}{l}-\quad<2 \text { children } \\
-\quad \geq 2 \text { children }\end{array}$ & $\begin{array}{c}53 \\
7\end{array}$ & $\begin{array}{c}44.1 \\
5.8\end{array}$ & $\begin{array}{l}49 \\
11\end{array}$ & $\begin{array}{c}40.8 \\
9.1\end{array}$ & 0.61 & $4 \cdot 73$ & 0.306 \\
\hline $\begin{array}{l}\text { Blood booster } \\
\text { suplementation }\end{array}$ & & & & & & & \\
\hline $\begin{array}{l}\text { - } \text { Adherent } \\
\text { - Non-adherent }\end{array}$ & $\begin{array}{c}53 \\
7\end{array}$ & $\begin{array}{c}44.1 \\
5.8\end{array}$ & $\begin{array}{c}54 \\
6\end{array}$ & $\begin{array}{c}45 \\
5\end{array}$ & 0.37 & $3 \cdot 77$ & 0.769 \\
\hline $\begin{array}{l}\text { How to consume blood } \\
\text { booster tablets }\end{array}$ & & & & & & & \\
\hline - Correct & 50 & 41.6 & 49 & 40.8 & 0.44 & 2.88 & 0.810 \\
\hline - Wrong & 10 & 8.3 & 11 & 9.16 & & & \\
\hline
\end{tabular}


Journal Maternal and Child Health, 2016, 1(2): 131-137

https://doi.org/10.26911/thejmch.2016.01.02.08

Table 3 The results of the multiple logistic regression analysis factors associated with anemia.

\begin{tabular}{lcccc}
\hline \multirow{2}{*}{ Dependent Variable } & \multirow{2}{*}{ OR } & p & \multicolumn{2}{c}{ 95\% CI } \\
\cline { 5 - 6 } \cline { 4 - 5 } & & Lower limit & Upper limit \\
\hline Eductational age & 0.35 & 0.013 & 0.15 & 0.80 \\
Nagelkerke R & 0.33 & 0.010 & 1.29 & 6.81 \\
Hosmer and Lameshow test & $21.4 \%$ & & & \\
\hline
\end{tabular}

Hosmer and Lemeshow test in Table 3 was used to test the suitability (goodness of fit) or in other words to test whether the model used was in accordance with empirical data or not.

The null hypothesis in this test was "the model had sufficiently explained the data (fit)" with the test criteria rejecedt the null hypothesis if the probability value was smaller or equal to the significance level that had been established ( $\mathrm{p}<0.05)$. Based on Table 3 obtained Chi Square value of 3.67 with a value of $p=0.721$ thus the multiple logistic regression model used was sufficient to be able to explain the data (fit).

Pregnant women with older gestational age were at risk of anemia $(\mathrm{OR}=$ $0.35 ; 95 \% \mathrm{CI}=0.15$ to $0.80 ; \mathrm{p}=0.013)$. Pregnant women who had higher education were at risk of anemia $(\mathrm{OR}=0.33 ; 95 \% \mathrm{CI}=$ 1.29 to $6.81 ; \mathrm{p}=0.010$ ).

\section{DISCUSSION \\ 1. The effect of gestational age on anemia in pregnant women}

Pregnant women with an older gestational age are at risk of anemia with $(\mathrm{OR}=0.35$; $95 \% \mathrm{CI}=0.15$ to $0.80 ; \mathrm{p}=0.013)$. The definition of anemia in pregnancy by CDC (2012) considers normal hemodilution occurring in pregnancy where hemoglobin levels are less than $11 \mathrm{~g} / \mathrm{dl}$ in the first and third trimesters, and less than $10.5 \mathrm{~g} / \mathrm{dl}$ in the second trimester (Creasi, 2009). Pregnant women at Prambanan Community Health Center mostly experienced anemia in TM III, as many as 44 study subjects
(36.6\%). These results were consistent with studies in the USA that anemia prevalence is $1.8 \%$ in TM I, $8.2 \%$ in TM II, and $27.4 \%$ in TM III (Al Farsi et al., 2011). The relationship between anemia and gestational age due to increased iron requirements during the second and third trimesters is $4.1 \mathrm{mg}$ higher than the prepregnancy requirement of $5.6 \mathrm{mg} /$ day (Morisson, 2011). Anemia in pregnancy in the third trimester can cause the mother to become weaker and iron in the blood to be divided for fetal growth in the uterus so as to reduce the binding capacity of iron in the mother's blood (Alene, 2014). Midwives at Prambanan Community Health Center provided information that all patients were at risk of anemia from TM I. However, it will be riskier if the anemia was only known in TM III, so it would be more at risk for labor bleeding.

\section{The effect of maternal education on anemia in pregnant women}

Pregnant women who had higher education were at risk of anemia with $(\mathrm{OR}=0.33$; $95 \% \mathrm{CI}=1.29$ to $6.81 ; \mathrm{p}=0.010$ ). Education greatly affects a person's ability to receive information. The higher the level of education, the easier it is to live healthy independently, creatively, and sustainable (Mubarak, 2007).

In Table 3, mothers whose education was in accordance with government programs (9 years of compulsory education) experienced anemia as many as 30 study subjects (63.8\%). Informant midwives said that anemia counseling carried 
out on classes of pregnant women and education could affect the occurrence of anemia, because pregnant women could choose foods that contained lots of iron.

\section{The effect of pregnancy interval on anemia in pregnant women}

Mothers who had a pregnancy interval of $>2$ years were at risk of anemia with $(\mathrm{OR}=$ $0.48 ; 95 \% \mathrm{CI}=0.08$ to $2.74 ; \mathrm{p}=0.402$ ). Pregnant women who had a non-risk pregnancy interval were suffering from anemia 58 (48.3\%) and 56 (46.6\%) were not anemic. This showed that the pregnancy interval did not determine a pregnant woman had anemia. Midwives interviewed at the Prambanan Community Health Center said that if pregnant women had a pregnancy interval that was too close, supervision of their nutritional status was lacking because they might still be breastfeeding, and their needs were divided for the first child so they were at risk of anemia.

\section{The effect of parity on anemia in pregnant women}

Close pregnancy interval was related to the parity of pregnant women, in mothers with high parity had a higher risk of anemia (OR $=2.92 ; 95 \% \mathrm{CI}=2.02$ to 4.59$)$. Parity is closely related to pregnancy interval and high parity has the potential for anemia (AlFarsi et al., 2011). Pregnant women with parity $>2$ children were at risk of anemia with $(\mathrm{OR}=1.7 ; 95 \% \mathrm{CI}=0.61$ to $4.73 ; \mathrm{p}=$ 0.306). In table 4 , parity <2 with anemia were as many as 53 of study subjects (44.1\%) and non-anemia as many as 49 study subjects (40.9\%).

\section{The effect of consuming blood booster supplementation on anem- ia in pregnant women}

Pregnant women who were adherent in consuming blood booster supplementation were at risk of anemia with $(\mathrm{OR}=1.18$; $95 \% \mathrm{CI}=0.37$ to $3.77 ; \mathrm{p}=0.769$ ). Blood bo- oster supplementation in Community Health Center was in accordance with Regulation of the Minister of Health of the Republic of Indonesia No. 88 of 2014 concerning blood booster tablet standards given to women of childbearing age and pregnant women. Blood booster tablet according to the standard contained iron equivalent to $60 \mathrm{mg}$ of iron (Ferro Sulfate) and folic acid $0.400 \mathrm{mg}$. Iron and folic acid are found in meat, fish and liver, which are relatively expensive, and may not be affordable to all people. Pregnant women who were adherent in consuming non-anemia blood booster tablets were 54 study subjects (45\%) and anemia as many as 53 study subjects (44.1\%). The presence of anemic pregnant women, even though they consume blood booster tablets due to not only blood booster tablets which affect anemia status, but their consumption patterns (Fatimah, 2011).

\section{The effect of how to consume blood booster supplementation on anem- ia in pregnant women}

Pregnant women who consumed blood booster tablets correctly had risk of anemia $(\mathrm{OR}=1.12 ; 95 \% \mathrm{CI}=0.43$ to $2.88 ; \mathrm{p}=$ 0.810). Midwives had made efforts to prevent anemia by checking $\mathrm{Hb}$ levels in all pregnant women and giving blood booster tablets according to the results of anemia examination. In Table 2, pregnant women who consume blood booster tablets correctly and still experienced anemia as many as 50 study subjects (41.6) and nonanemia as many as 49 study subjects (40.8). Blood booster tablets were not the only way to overcome anemia, but it should be followed by the intake of nutrients that contain iron. Blood booster tablet supplementation was the right choice to meet iron requirements during pregnancy.

The government program to overcome iron nutritional anemia in pregnant 
women through iron supplementation had been carried out at the Prambanan Community Health Center. The coverage of giving high blood booster tablets (92.34\%) but pregnant women were still suffering from anemia indicated that the program had been running but had not been able to overcome the problem of anemia. The results of this study indicated that there were other factors that influenced anemia. Factors that influence anemia included purchasing power of foods containing iron and folic acid because most study subjects had income $<$ UMR.

Midwives, nutrition workers, and pregnant women interviewed stated that the cause of high rates of anemia was a lack of iron-containing food intake in pregnant women. Midwives had given blood booster supplements to all pregnant women, and nutrition workers had been counseling pregnant women who are anemic. Nutrition officers only conducted counseling for pregnant women who suffered from anemia, because those women were referred by the midwife to be given counseling in the nutrition department. Counseling given by nutritional officers that was not comprehensive for all pregnant women resulted in some pregnant women did not know the intake of foods containing $\mathrm{Fe}$ for prevention of anemia. Education regarding anemia by midwives and nutrition counseling by nutrition officers that had been carried out needed to be improved in an effort to prevent anemia in all pregnant women.

\section{REFERENCES}

Alene KA, Abdulahi MD (2014). Prevalence of Anemia and Associated Factors among Pregnant Women in an Urban Area of Easthern Ethiopia. Hindawi Publishing Corporation. http://dx.doi.org. Diakses 5 Januari 2016.
Al-Farsi YM, Daniel RB, Martha MW, Howard JC, Mohammed AA, Henk CW (2011). Effect of High Parity on Occurrence Of Anemia In Pregnancy: A Cohort Study. BMC Pregnancy and Childbirth. 2011(11): 1-7. www.biomedcentral.com. Diakses 1 September 2016.

Bahar H (2006). Infeksi, Perbaiki Gizi Ibu hamil. Yogyakarta: Pustaka Rihana.

Bedi R, Rekha A, Rashmi G, Swati P, Rakesh S (2015). Maternal Factors Of Anemia In 3rd Trimester Of Pregnancy And Its Association With Fetal Outcome. International Multispecialty Journal of Health 1(7):9.

Creasy RK, Robert R, Jay D, Charles JL, Thomas RM (2009). Maternal fetal Medicine Principles and Practice Sixth Edition. Philadelphia: Saunders Elsevier. Diakses 5 Januari 2016.

Creswell JW (2012). Research Design Pendekatan Kualitatif, Kuantitatif, dan Mixed. Yogyakarta: Pustaka Pelajar.

Dinas Kesehatan DIY (2013). Profil Kesehatan Propinsi DIY. Yogyakarta.

Fatimah S, Veni H, Burhanuddin B, Zulkifli A (2011). Pola Konsumsi dan Kadar Hemoglobin Pada Ibu Hamil Di Kabupaten Maros Sulawesi Selatan. Makara, Jurnal Kesehatan 15(1): 3136.

Haider BA, Ibironke O, Molin W, Donna S, Majid E, Wafaie WF (2013). Anemia, Prenatal Iron Use, and Risk of Adverse Pregnancy outcomes: Systematic Review and Meta-Analysis. BMJ 2013 (346): 1-19.

Huang LL, Gowreesunkur P, Su MW, Lin LZ, Hui T (2015). The Influence of Iron-deficiency Anemia during the Pregnancy on Preterm Birth and Birth Weight in South China. Journal of Food and Nutrition Research 3(9): 570-574. 
Masukume G, Ali SK, Louise CK, Philip NB, and Gill N (2015). Risk Factors and Birth Outcomes of Anaemia in Early Pregnancy in a Nulliparous Cohort. PLOSONE 10(4): eo122729.

Morrison JC, Marc RPJ (2011). Anemia Associated with Pregnancy. Global Libary of Women's Medicine 2011 DOI 10.3843/GLOWM.10164. Diakses 5 Januari 2016.

Mubarak WI (2007). Promosi Kesehatan Untuk Kebidanan. Jakarta: Graha Ilmu.

Noran M, Mohammed M (2015). The Impact of Maternal Iron Deficiency and Iron Deficiency Anemia on Child's Health. Saudi Medical Journal, 36(2): 146-149.

Ononge S, Oona C, Florence M (2014). Haemoglobin Status and Predictors of Anemia Among Pregnant Women in Mpigi Uganda. BMC Research Notes,
(7):712. www.biomedcentral.com. Diakses: 1 September 2016.

Proverawati A (2011). Anemia dan Anemian Kehamilan. Yogyakarta: Nuha Medika.

Sharma, JB, Meenakshi S (2010). Anemia in Pregnancy. JIMSA 23(4): 253-260.

Siriwong O (2012). Anemia in Pregnant Women Attending the Antenatal Care Clinic, Mae Sot Hospital. Thai Journal of Obstetrics and Gynaecology October (20): 186-190.

Soh KL, Eusni RMT, Salimah J, Soh KG, Norhaslinda BR, Rosna AR (2015). Anemia among Antenatal Mother in Urban Malaysia. Journal of Biosciences and Medicines 2015 (3): 6-11. 